\title{
Behavior of debris flows monitored on test slopes of Kamikamihorizawa Creek, Mount Yakedake, Japan
}

\author{
Hiroshi SUWA ${ }^{1}$, Kazuyuki OKANO ${ }^{2}$ and Tadahiro KANNO ${ }^{3}$ \\ ${ }^{1}$ Disaster Prevention Research Institute, Kyoto University (Kyoto 611-0011, Japan) \\ ${ }^{2}$ Graduate School of Science, Kyoto University (Kyoto 606-8502, Japan. Now in Asia Air Survey Co. Ltd. after graduation) \\ ${ }^{3}$ Matsumoto Sabo Office, Ministry of Land, Infrastructure, Transport and Tourism (Nagano 390-0803, Japan)
}

Kamikamihorizawa Creek on the slopes of Mount Yakedake, Nagano Prefecture, was selected as an observation site for debris flows due to the high frequency of debris flow and instrumented with monitoring equipments in 1970: seven years after the last phreatic explosion of this volcano. The monitoring system was improved by adding speedometers, stage meters, seismometers and so on. Over the last 30 years, data were obtained from 88 debris-flow events that contained more than 200 episodes of debris-flow surges. The data indicated the following common features related to debris flows. 1) High-intensity rainstorms with a short duration of about $10 \mathrm{~min}$ were more likely to trigger debris flows than storms with large rainfall for longer durations. 2) The threshold of rainstorm intensities for debris flows increased due to the changes in hillslope hydrology. 3) The hydrograph of debris-flow surges showed mass and boulder focusing on the front due to mechanical processes. 4) Pulsation and superelevation were common features that were significant as hazard-inducing factors. 5) Monitoring of seismic signals from debris flows is useful for hazard warning as well as for estimating debris-flow hydrographs. 6) Evaluation of hazard-prone locations downstream in the fan is possible by analyzing the interaction of the flows and the fan morphology. 7) Moderation of debris-flow hydrographs is achievable using new net dam or flat-board breakers in the lower reaches of gullies.

Keywords: debris flow, monitoring, countermeasure facilities, Kamikamihorizawa Creek, Mount Yakedake, volcanoes, hillslope hydrology

\section{INTRODUCTION}

Floods and high tides due to typhoons were significant hazards in Japan after World War II. Owing to the developments in the economy, countermeasures to protect many settlements from these hazards were considerably improved by the construction of defensive facilities along rivers and coasts. However, other numerous settlements and infrastructures that were vulnerable to slope hazards were left as they were, resulting in a series of disasters. For instance, several severe disasters caused by debris flows occurred in the late 1960s and early 1970s: the August 1967 Uetsu Rainstorm Disaster (Iwasaki et al., 1968), the August 1968 Hidagawa Bus Accident (Saito, 1973), and the August 1969 Hokuriku Rainstorm Disaster. Countermeasures and preparedness against the hazards were insufficient in these incidents. One reason for this was that data on debris-flow behavior were unavailable at that time. Field debris-flow data were indispensable for improving this situation.

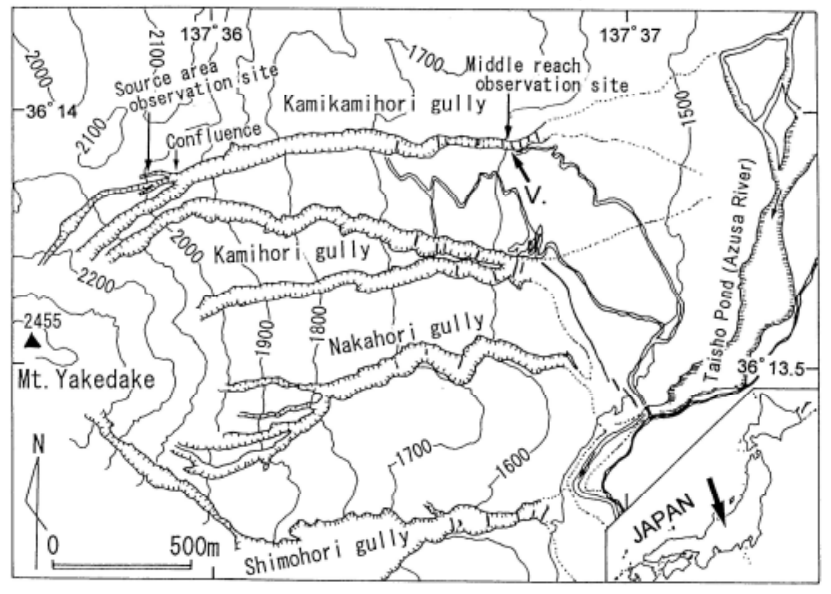

Fig. 1 Debris-flow monitoring sites at Mount Yakedake

\section{START OF DEBRIS-FLOW MONITORING AT MOUNT YAKEDAKE}

To address this lack of data, a group from the Disaster Prevention Research Institute at Kyoto University started field observations of debris flows at Kamikamihorizawa Creek, Mount Yakedake, Nagano, in the summer 1970 rainy season (Fig. 1) 

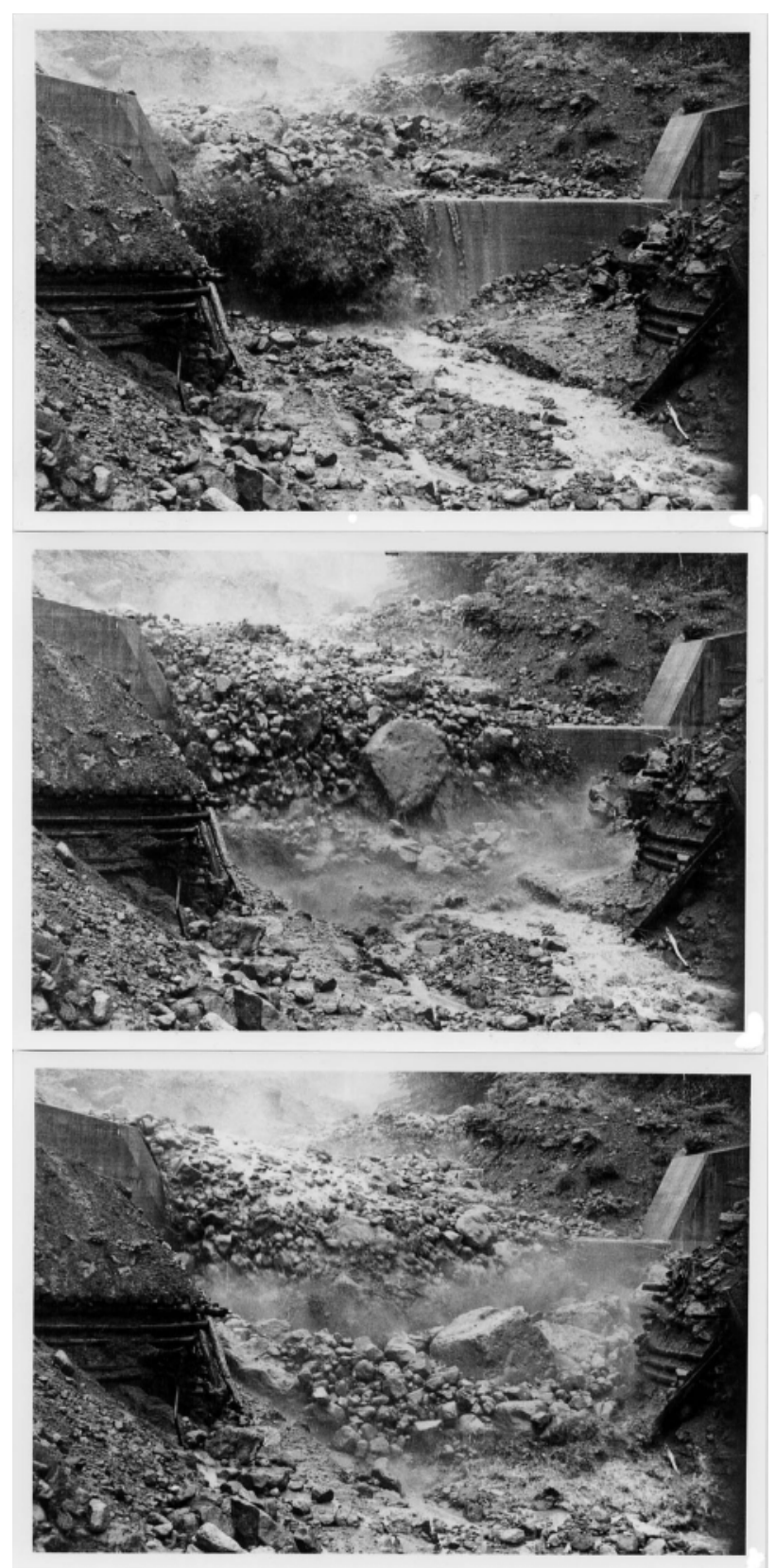

Fig. 2 Photos of the August 3, 1976 debris flow descending Kamikamihorizawa Creek, shown in sequence $2 \mathrm{~s}$ apart. After Okuda et al. (1980).

in cooperation with the Matsumoto Sabo Construction Office of the Ministry of Construction (Suwa et al., 1973). They first installed a video camera near the middle reach observation site to take pictures of debris flows. They also installed additional equipment over the following years (Okuda et al., 1980), including video cameras to analyze the motion, two types of speedometers (an electromagnetic Doppler speedometer and a spatial-filter speedometer) (Itakura and Suwa, 1989) to obtain the surface velocity, seismometers to measure ground tremors, an ultrasonic stage sensor to measure the flow depth, and rain gauges. An online system controlled by multiple wire sensors synchronized the equipment operation with debris-flow movements.

Kamikamihorizawa Creek was selected because of the high frequency of debris flows it experiences, more than ten per year in the 1960s. The high frequency was due to the activation in gully erosion after the last phreatic eruption of Mount Yakedake in 1962, in which the explosion was from new fissures that opened at the headwaters of this creek. The volcano consists of lava domes of andesite surrounded by numerous sets of pyroclastic-flow deposits and debris-flow deposits. The report of the Matsumoto Sabo Office (1979) lists more than 80 eruptions of this volcano since 1585. The 1915 eruption induced a landslide that dammed the Azusa River to form a new lake called Taisho Pond. This lake was stabilized by a dam completed in 1928, which fixed the elevation of the distal fan at $1490 \mathrm{~m}$ above sea level (ASL).

The region has a temperate humid climate with annual precipitation of about $2500 \mathrm{~mm}$; nearly two-thirds falls as rain while the rest occurs as snow. The watersheds and the fans are moderately vegetated except the slopes of the gully walls where soil removal continues. The slopes are neither farmed nor inhabited because the area belongs to the Central Japan Alps National Park and the Kamikochi National Forest.

\section{DEBRIS-FLOW PHOTOGRAPHS}

Taking photographs of debris flows using the online system was difficult, and none were obtained in the first year of operation. Motion pictures of the September 18, 1970 debris flow were captured by a manually operated 8-mm movie camera; these were the first visual data related to debris flows. Automatic acquisition of debris-flow data gradually became more successful starting in 1971 (Okuda et al., 1980).

Figure 2 shows pictures of the August 3, 1976 debris flow rushing over a ground sill located near the middle reach observation site. This debris-flow surge with a frontal velocity $3.8 \mathrm{~m} / \mathrm{s}$, a peak discharge $100 \mathrm{~m}^{3} / \mathrm{s}$, and total volume of $6000 \mathrm{~m}^{3}$ ran over the 16-m-wide spillway and along the channel at an $8^{\circ}$ slope. Integration of these visual records as well as the data related to debris-flow motion was used to characterize the dynamic processes of the flows, as described in Section 6. The observations at Mount Yakedake have also helped explain the hillslope hydrology relevant to debris-flow initiation and slope erosion (Suwa and Okuda, 1980; Okunishi and Suwa, 1985; Suwa and 


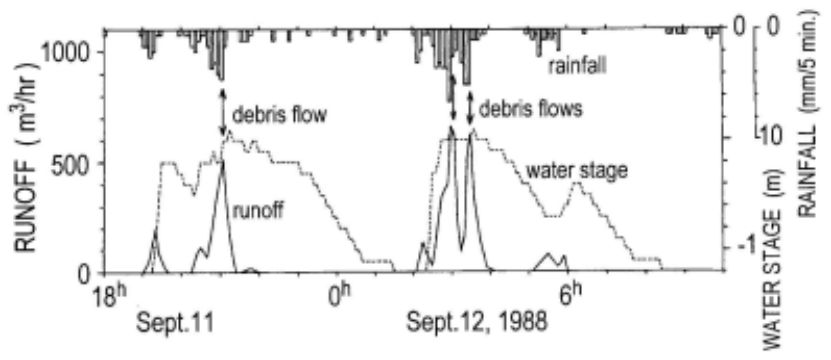

Fig. 3 Debris-flow initiation and 5-min rainfall, surface runoff, and subsurface perched-water stage. After Suwa (1989).

Okuda, 1988; Suwa and Yamakoshi, 1999; Yamakoshi et al., 2001), the processes related to debris-flow motion (Okuda et al., 1980; Suwa et al., 1993), and deposition (Okuda et al., 1981; Suwa and Okuda, 1983). Data from 88 debris-flow events obtained since 1970 were compiled in a series of the technical reports by the Matsumoto Sabo Office of the Japanese Ministry of Land, Infrastructure, Transport, and Tourism.

\section{PREVIOUS AND CURRENT DEBRIS-FLOW MONITORING}

Debris-flow monitoring has been conducted elsewhere, both inside and outside Japan, to provide hazard warning in serious cases and to obtain data to improve our understanding of debris flows. Monitoring in Japan has been carried out in several areas, including Mount Sakurajima, Kagoshima since 1973 (e.g., Saita et al., 1980; Haruyama et al., 1984); the Urakawa River, which is a tributary of the Himekawa River, Nagano since 1975 (Kataoka et al., 1984); the Namekawa River, which is a tributary of the Kiso River, Gifu since 1982 (Ishikawa et al., 1985; Ikeda et al., 1998; Ikeda and Hara, 2003); the Ohsawagawa River on the slopes of Mount Fuji, Shizuoka since 1972 (Nanzaka and Iwata, 1989); and the Mizunashigawa River on the slopes of Mount Unzen, Nagasaki since 1991 (Suwa and Yamakoshi, 1997; Suwa and Yamakoshi, 1999).

Outside Japan, monitoring was conducted for instance in the Guxiang-gou Gulley in Tibet in 1964-1965 (Ma, 1994) and 1992-1993 (Suwa et al., 1994); in the Jiangjia-gou Gulley, Yunnang, China since 1973 (e.g., Li, J. et al., 1983; Mizuyama et al., 1992; Suwa et al., 1997); on the slopes of Mt. Thomas, New Zealand (Pierson, 1980); in the valley of the Muddy River on Mount St. Helens, Washington, USA during 1981-1983 (Pierson, 1986); in the Bebeng River on Mount Merapi, Indonesia during 1991-1995 (Suwa and Sumaryono,
1996; Lavigne et al., 2000a; 2000b), in the Kali Curah Lengkong River on Mount Semeru, Indonesia since 2001 (Lavigne and Suwa, 2004; Thouret et al., 2007); on the slopes of several ravines on Mount Pinatubo, Philippines since 1992 (e.g., Marcial et al., 1996); at the Moscardo Torrent in Italy since 1989 (Arattano et al., 1997; Marchi et al., 2002); and in Acquabona Creek, Italy since 1997 (Genevois et al., 2000), as well as other sites.

These sites were selected because of the high frequency of debris flows due to erodible and unstable slope conditions. The sites were often selected on the slopes of active volcanoes. The debris-flow frequency is markedly high at volcanoes, especially during syn-eruption and post-eruption periods. Ash fall as well as wild fires drastically changes the hydrologic response of slope surfaces during rainstorms by increasing the runoff ratio, which leads to a high frequency of debris flows. Debris-flow monitoring at these sites has greatly contributed to understanding the mechanisms of debris-flow initiation, motion, and termination. The key lessons learned are described below, based mainly on the results obtained from the monitoring of Kamikamihorizawa Creek.

\section{STORM CONDITIONS FOR DEBRIS FLOWS}

Even if the duration of rainfall is short, high rainstorm intensities can trigger debris flows in volcanic torrents. Figure 3 shows an example of the hydrologic response at the headwaters of Kamikamihorizawa Creek that led to debris flows (Suwa, 1989). The diagram shows that the high rainstorm intensity raises the subsurface perched-water stage in the deposits. The peaks in the perched-water stage coincide with the increases in surface runoff that trigger debris flows. This temporal coincidence of debris flow and surface-runoff peak indicates that debris flows are not initiated by landslides, but by the drastic incorporation of deposits in the gully due to the appearance of rapid storm runoff.

Temporal changes are found in the rainfall intensity for debris flows over years (DPRI Kyoto Univ., 2008). Figure 4 uses red circles to show the peak intensities of hourly rainfall that triggered debris flows, and open circles for those that triggered no debris flow for all rainfall events since 1975. In a similar way, Fig.5 shows the relationship between the peak of 10-min rainfall and debris flow occurrence. Both diagrams indicate that the lower limit intensities for debris flows after 1985 are 


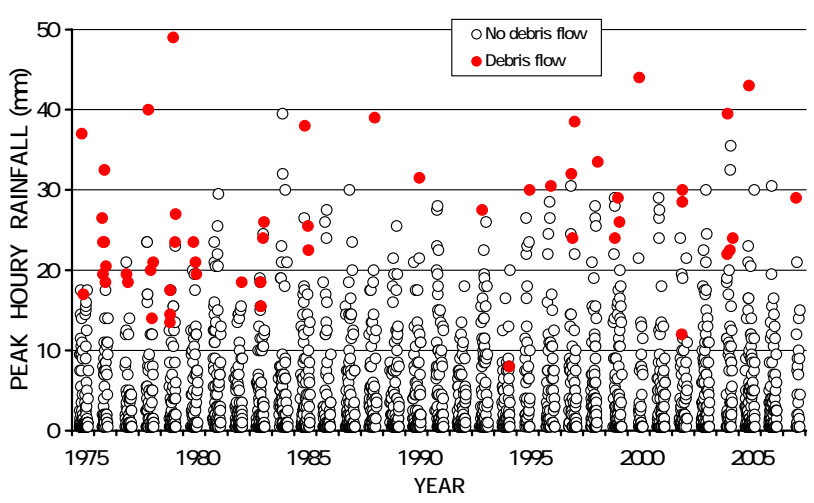

Fig. 4 Relationship between debris flow occurrence and the peak of hourly rainfall, after DPRI Kyoto Univ. (2008)

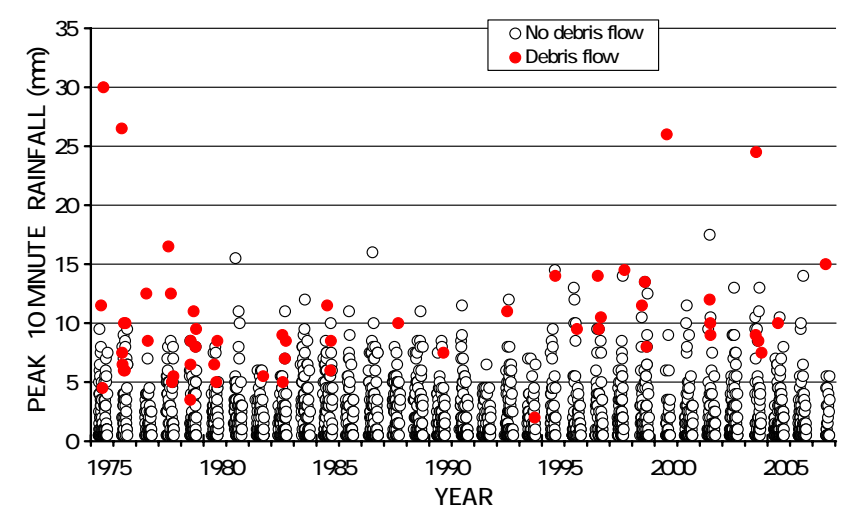

Fig. 5 Relationship between debris flow occurrence and the peak of 10-min rainfall. After DPRI Kyoto Univ. (2008)

somewhat higher than those before 1985. This means debris flows are not as likely to occur as they were in the past.

A similar trend might exist in the longer temporal trend in the hydrologic response of hillslopes to rainstorms after a volcanic eruption. Yamakoshi et al. (2001) described the changes in hillslope hydrology caused by revegetation or vegetation recovery. The changes occur largely in the first few years after volcanic eruptions as well as more gradually over a period of several decades (Yamakoshi and Suwa, 2000). These temporal changes decrease the storm-runoff ratio of hillslopes resulting from a combined effect of the increase in infiltration coefficient and roughness parameter, and the decrease in contributing area for runoff generation.

\section{DEBRIS-FLOW MOTION}

The monitoring system, consisting of multiple wire sensors, video cameras, and other equipment, revealed the features of debris-flow motion described below. Integration of monitoring data, eyewitness information, and topographic survey data indicated that the rapid appearance of storm runoff in the headwaters induces muddy hyperconcentrated stream flows, which turn into debris-flow surges in the source reaches around $1950 \mathrm{~m}$ ASL, and further incorporate deposits to increase during the travel downstream. As the flows decelerate, their volume decreases, leaving scattered deposits. They eventually come to rest on the gentle slopes of the lower reaches in the gully or in the fan. Extraordinarily large debris flows sometimes overrun the distal fan and reach the main stream of the Azusa River. The travel distance is clearly controlled by the scale and mobility of the debris flows (Okuda and Suwa, 1984).

\subsection{Velocity and mobility}

Multiple wire-sensors were installed at 30 locations from the source reaches at $1950 \mathrm{~m} \mathrm{ASL}$ through to the distal fan at $1500 \mathrm{~m}$ ASL. They generated data related to the spatial change in frontal velocities of debris flows, as shown in Fig. 6. Integration of these data indicated that frontal velocities as large as $6-16 \mathrm{~m} / \mathrm{s}$ appeared at the upper reaches with slope angles from $14-26^{\circ}$. However, they decreased to less than $4.5 \mathrm{~m} / \mathrm{s}$ at the middle reach observation site, and decelerated to less than $1 \mathrm{~m} / \mathrm{s}$ in the termination reaches (Okuda et al., 1980; Suwa and Okuda, 1983; Suwa, 1989).

The data have indicated that large-scale debris flows with high mobility tend to have higher frontal velocities. The mobility of debris flows may be evaluated by the velocity coefficient, defined as the ratio of the frontal velocity $V_{\mathrm{f}}$ to shear velocity $u_{*}$ which is approximately equal to $\sqrt{g h \sin \theta}$, in which $\theta$ is the channel floor slope angle, $h$ is the flow depth, and $g$ is the acceleration due to gravity. This coefficient is proportional to $f^{-1 / 2}$ where $f$ is the drag coefficient. Figure 7 shows the relationship between the velocity coefficient and the relative depth of debris flows, where the relative depth is defined as the ratio of flow depth to the median diameter of the solid particles in the flow. The figure shows that the mobility of the Kamikamihorizawa debris flows is much smaller than that of the Jiangjia debris flows in China (Suwa et al., 1997).

\subsection{Hydrograph and structure}

Observations have revealed that the debris flows are hydraulically unsteady and non-uniform. Figure 8 shows an example of the hydrographs of the July 21, 1985 debris flow, where the flow consisted of an abrupt rise at the front and 


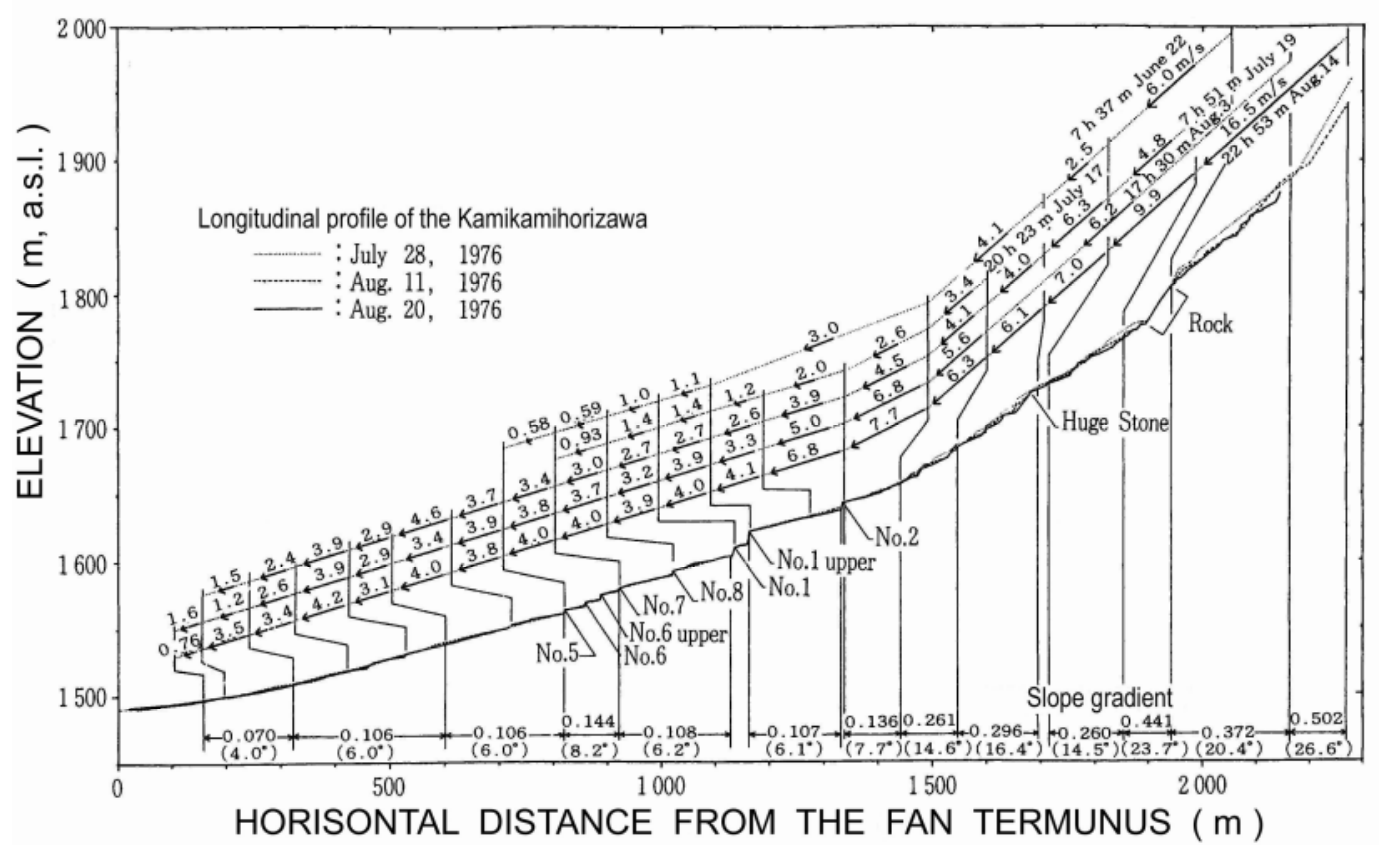

Fig. 6 Frontal velocity of debris flows along Kamikamihorizawa Creek. After Okuda et al. (1980).

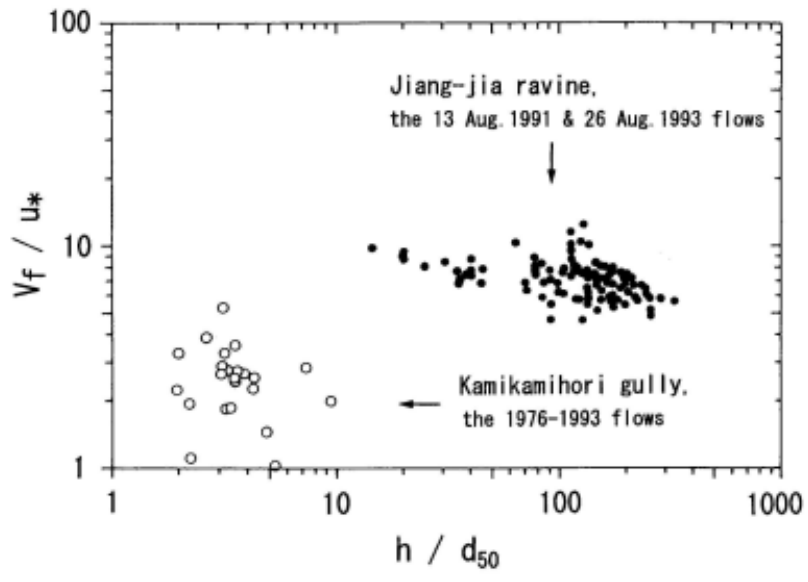

Fig. 7 Relationship between velocity coefficient and relative depth. After Suwa et al., 1997.

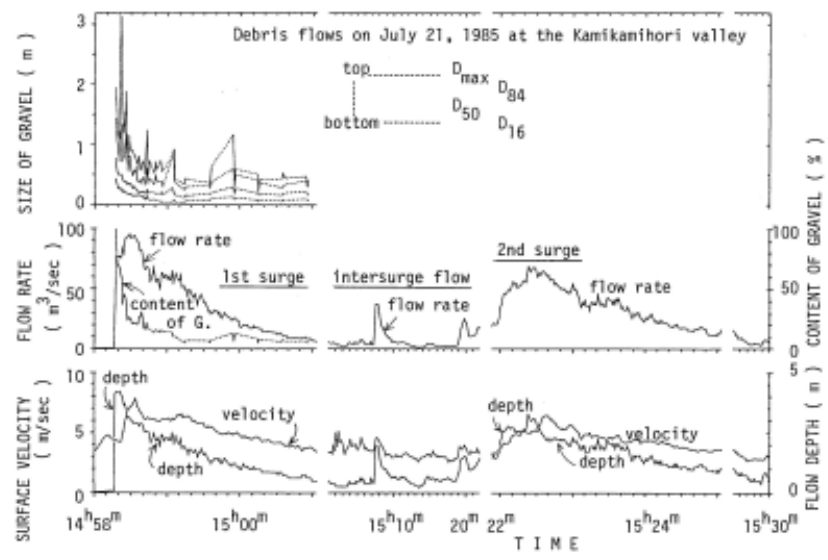

Fig. 8 Hydrograph of the July 21, 1985 debris flow showing the gravel content and size parameters. After Suwa (1988)

a recession limb behind. However, the surface velocity at the front was significantly smaller than

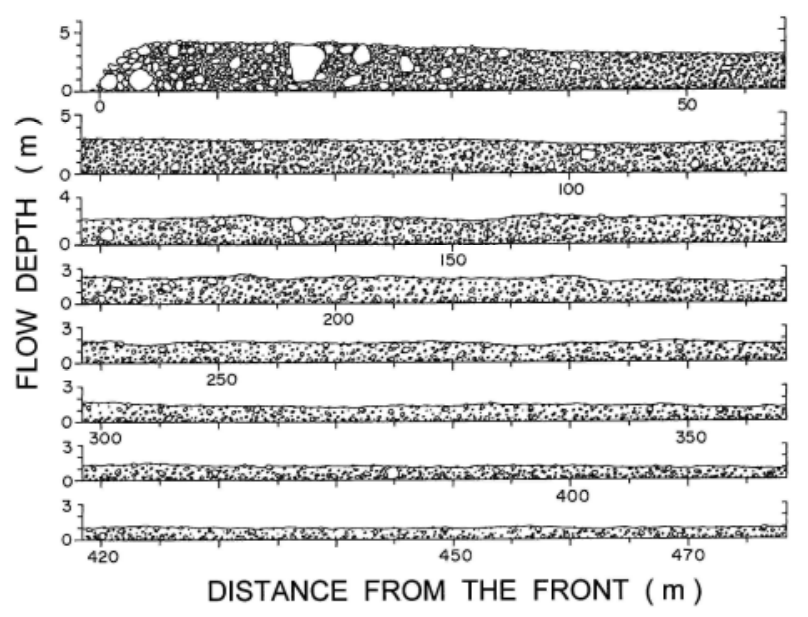

Fig. 9 Longitudinal cross-section of the first surge of the July 21, 1985 debris flow based on the data shown in Fig. 8. After Suwa (1989)

the velocities in the middle and at the back. This low velocity is ascribed to large internal friction caused by the higher frequency of mutual collision and the interlocking structure in the massive boulder-filled frontal part that causes a marked difference in the vertical velocity gradients at the front and rear. Overall, the data indicate a common feature where peaks in hydraulic parameters appear in order of flow depth, discharge, and then surface velocity.

The temporal change in discharge shows a significant focusing of mass on the surge front. This is clear in Fig. 9, which shows the longitudinal cross-section of the first surge of the July 21, 1985 debris flow based on the same data as in Fig. 8. The horizontal axis, the distance from the surge front, 


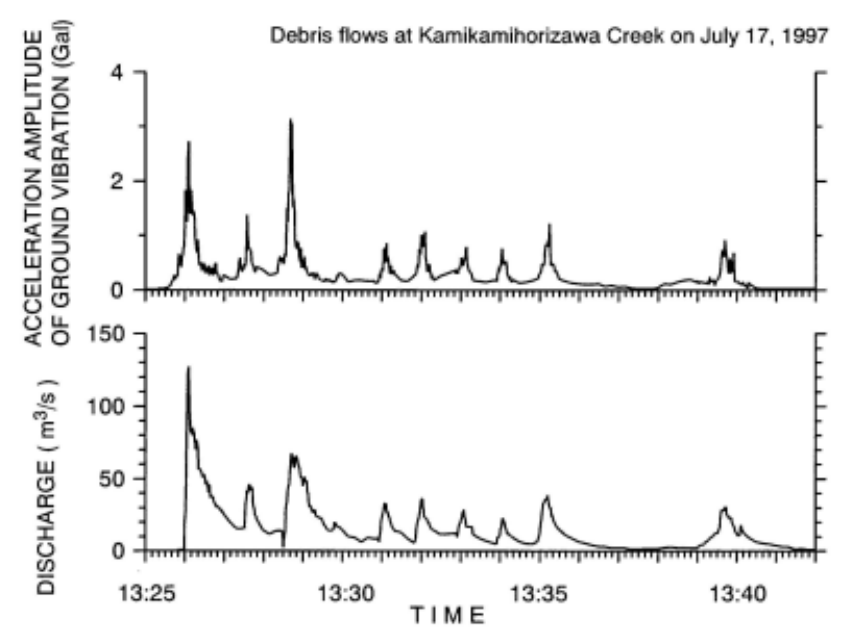

Fig. 10 Acceleration amplitude of the ground tremor accompanying the July 17, 1997 debris-flow discharge. After Suwa et al. (2003)

corresponds to the time integral of surface velocity.

The focusing of large boulders towards the surge front is a common feature in boulder-rich debris flows, and is the result of a combination of a few factors. Takahashi (1980) attributed the faster transportation of larger boulders towards the front to the combination of two processes in the flow: an inverse grading process resulting from the upward migration of larger boulders due to the dispersive pressure, and the upward increase in the flow velocity that is common in open-channel flows. Namely, larger boulders tend to migrate upwards to be exposed to higher velocities, and are transported more quickly to the front. Suwa (1988) had a different explanation for this boulder focusing. The terminal velocity of boulders on steep slopes is larger than the mean velocity of the surrounding slurry, and the larger boulders attain higher terminal velocities to arrive earlier at the front. In addition, larger boulders are assumed to be transported faster even if the inverse grading effect does not work, because the larger boulders are exposed to higher velocities if the transportation mode is near to bed load transportation, i.e., if the flow mode is hyper-concentrated stream flows. Under these conditions, taller or larger boulders are exposed to higher velocities, depending on the height above the bottom. The actual focusing of large boulders is caused by a combination of these major factors, and results in the formation of boulder-rich frontal part which is often called as boulder dam.

Boulder dams have a number of different features. In some cases, all the interstices between the boulders are filled with slurry matrix, while in the others, the interstices remain completely empty. Okano et al. (2009) analyzed the rainstorm control on such different features, and found that large, longer-duration rainfalls, for instance, in the previous $24 \mathrm{hr}$ increase the water content in the source deposits, causing debris flows with large boulder dams in which the inter-boulder spaces are filled. However, the combination of small rainfalls in the previous $24 \mathrm{hr}$ and large rainfall intensities with durations as short as $10 \mathrm{~min}$ cause low water content in the source deposits, resulting in debris flows with small boulder dams in which the inter-boulder spaces are completely empty.

\subsection{Ground tremors and roaring sounds}

Debris-flow movement is accompanied by ground tremors and sounds like long-lasting thunder, the intensity of which increases as the debris-flow surges approach the monitoring sites. Figure 10 shows the temporal change in the acceleration amplitude of ground tremors along with a hydrograph of a debris flow. The time series data clearly show the approach and passage of the surges. The seismic signal can be monitored before the arrival of the surge at the monitoring site, showing that debris-flow warning using seismometers would be effective for the mitigation of hazards. Attempts have been made to develop an intelligent system to warn about debris flows using seismic signal detection (e.g., Kurihara et al., 2007).

Studies of the debris-flow seismicity with this in mind have resulted in several new insights. The intensity of the ground tremor increases as it approaches the measuring location and decreases as the surge passes, as shown in Fig. 10. The dominant frequency, i.e., the peak spectrum of the ground tremor, is in the $20-30-\mathrm{Hz}$ range during the approach and in the 40-60- $\mathrm{Hz}$ range as the flow passes by (Suwa and Okuda, 1985). This may due to collision of the larger boulders in the front that contributes strong wave radiation with longer periodicity, while collision of smaller gravel particles contributes weaker radiation with shorter periodicity. A clear positive correlation (correlation coefficient of 0.89) was found between the peak of the flow discharge and the peak of the tremor acceleration amplitude. This strong correlation suggests that estimation of the peak discharge is possible by monitoring the acceleration amplitude (Suwa et al., 2000). There is also a positive correlation (coefficient of 0.98 ) between the total volume of the surges and the time integral of the acceleration amplitude of the tremors. This strong correlation suggests that estimation of debris-flow volume is possible using the time integral of the acceleration amplitude (Suwa et al., 2000). A small fraction on the order of $10^{-3}$ of the total kinetic energy consumed as internal and boundary frictions 


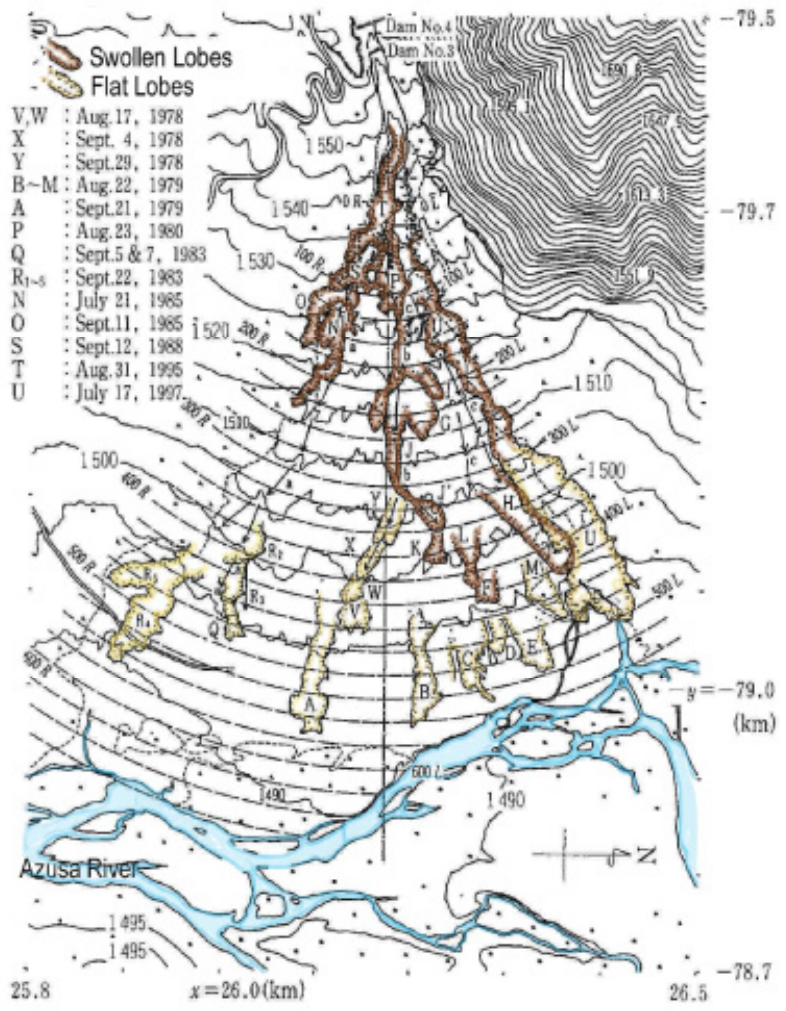

Fig. 11 Superposition of debris-flow lobes on the Kamimaihorizawa fan during 1978-1997, modified after Suwa and Yamakoshi, 1999. Routes (a), (b), and (c) denote the three main orientations in which the previous debris flows were conveyed.

is radiated as elastic-wave energy by the passage of debris-flow surges. The conversion efficiency in debris flows from the loss of kinetic energy to elastic-wave energy through friction is estimated at about $10^{-3}$, which is much smaller than efficiencies on the order of $10^{-1}$ found in the case of earthquakes (Suwa et al., 2003).

\subsection{Pulsation}

Although debris flows may descend a creek as a single episode in minor cases, they can also rush down as a series of pulsation episodes in major cases. Figure 10 shows such an example, in which nine surges occurred during a single 15-minute period. Note that five of them descended at approximately 1-minute intervals. Similar pulsations in debris flows have been observed elsewhere as well, at locations such as Mount Unzen, Japan (Suwa and Yamakoshi, 1999), Mount Merapi, Indonesia (Suwa and Sumaryono, 1996), and Jiangjia Gully in Yunnan Province, China (Davies et al., 1991; Suwa et al., 1997). The surges in these cases repeat every 1-5 minutes, and periodic pulsations were often observed. There are four possible causes for this pulsation phenomenon (Suwa et al., 1997): sensitive response to strong rainfall intensities, a successive formation of a landslide dam and its breach, failure in the force balance between the shear stress and shear strength of the source slurry, and growth of instability in the flow motion.

The first cause is understandable from the relationship between strong rainfall intensities and debris flows as shown in Fig. 3.

The second cause arises from the successive breach of multiple landslide dams due to rainstorms; these may trigger debris-flow surges one after another. However, this may not apply to Kamikamihorizawa Creek, where debris flows are the result of erosion by storm surface runoff, not from landslide-dam breaches.

For the third cause, if shallow earth flow due to rainfall provides the source materials of viscoplastic slurry to the source reaches, the slurry layer may start moving as soon as the shear stress overcomes the shear strength of the layer as the depth of the layer increases. This process might not apply to Kamikamihorizawa Creek either because the materials in the source are not necessarily viscoplastic.

The fourth cause creates a pulsation as follows. Even if a debris flow moves steadily at the source reaches, it may transform into a series of pulses due to instability while traveling a long distance on a steep slope. The fourth cause is most plausible for Kamikamihorizawa Creek as well as the Jiangjia Gully because of the presence of a strong periodicity in the pulsation series.

It has been suggested that water flows in stepped channels can develop pulsations, so the check dams at the field site could affect the surge periodicity. However, pulsation in debris flows has also been observed in the channel reaches above the reaches where check dams have been constructed, so the effect of the check dams on pulsation is minor, if it is a factor at all.

\subsection{Superelevation}

Figure 2 shows that the top surface of the debris flows is inclined transversally. This phenomenon is referred to as superelevation of debris flows. Debris flows leave levees of boulders on both sides of the channels in which they travel. The difference in height between the levees on each side provides data about the debris-flow velocities (Suwa et al., 1983). Superelevation occurs as a process where the top surface of the flow is higher on the outer slopes than on the inner slopes in a winding channel resulting from the balance between the centrifugal force and the centering force in the flows, which is maintained by super-elevation that 
provides centering force to the flows. Traces of debris-flow superelevation are sometimes found not only in boulder-filled levees but also as mud lines, which show the highest extents of mud left on the sidewalls (Suwa and Yamakoshi, 2000), or in the clear-cut extents on the forested slopes along the routes traveled (Suwa and Nakaya, 2007). Super-elevation traces make it possible to estimate flow velocities over devastated areas. The superelevation of debris flows often controls the extent of the areas of affected by debris-flow hazards (e.g., Plafker and Ericksen, 1978). The evaluation of the superelevation effect is therefore essential for assessing the potential of debris-flow hazards.

Field observations of debris-flow levees that exhibit negative super-elevation, possibly the result of longitudinal non-uniformity, do not invalidate the use of superelevation to estimate dynamics, but do indicate the need for caution. The levees left on the fan are not always simple, and may be complicated in some cases by the superposition of multiple debris-flow surge depositions and the intermittent erosive action of stream-water flows. Selecting a set of levees left by a single debris-flow surge from the complicated configuration of deposits in the fan is essential when using superelevation analysis to estimate dynamics.

\section{DEBRIS-FLOW DEPOSITION}

Debris flows reach the fan if they are large enough and have high mobility. However, they will come to rest in the gully above the fan apex and not reach the fan if they are small and have low mobility. Proceeding into the fan, they descend the slopes confined in a fan-head trench and inundate the area below the terminal end of the trench. Fan-head trenches are formed by floods that follow an extraordinarily large debris-flow event. Although the succession of ordinary-scale debris flows forces the trench termination point to migrate upwards along the course due to the filling of the trench with deposits, the arrival of the inundation region at the fan apex provides a chance for the travel course to migrate laterally on the fan, as illustrated by the arrow groups of (a), (b), and (c) in Fig. 11. These spatial alterations of debris-flow deposition ensure that the alluvial cones remain concentric. Prediction of the interaction between debris-flow inundation and these fan-morphologic processes is significant for the assessments of hazard potentials.

Debris flows leave collective deposits on the fan surface, as illustrated in Fig.11. The units are referred to as debris-flow lobes (e.g., Hooke, 1967).
The figure shows two types of lobes: swollen and flat. Swollen lobes have steep fronts, referred to as snouts (Johnson, 1970), and steep marginal slopes in which boulders are supported not by a sandy matrix, but by interlocking boulders. Swollen lobes are also characterized by the frontal focusing of boulders, which is similar to the boulder dam in motion. This type of lobe often appears as if a boulder dam suddenly froze in place. On the other hand, flat lobes do not have any marked snouts or marginal steep slopes. They appear as thin deposits in which boulders are sparsely scattered and supported by a sandy matrix (Suwa and Okuda, 1983).

\section{TEST OF NEW COUNTERMEASURES}

Field testing of new countermeasures against debris flows has been conducted since 1974 in conjunction with the monitoring of debris flows at Kamikamihorizawa Creek (DPRI Kyoto Univ., 1975).

\subsection{Rectangular grid net debris-flow breaker}

A new debris-flow breaker made of a wire net was installed as shown in Fig. 12 and tested during 1974-1978 at a site at $1660 \mathrm{~m}$ ASL, about $100 \mathrm{~m}$ above the No. 2 dam on a $14^{\circ}$ slope. The 2 -m grid net made of $16-\mathrm{mm}$ steel wire rope was cut by the July 19, 1974 debris flow, not due to excessive loading, but due to abrasion by the flow passage. The ropes were replaced with thicker $28-\mathrm{mm}$ ropes (Kobe Steel Ltd., 1975; Kobe Steel Ltd., 1978). Although the net breaker trapped the August 9, 1977 moderate-scale debris flow after the repair, this type of net should not be installed in gullies where the slope is so steep that debris flows still have enough kinetic momentum to destroy the net. A better location would be on the reaches of gentler slopes near the gully exit.

\subsection{Flat-board debris-flow breaker}

A flat-board debris-flow breaker was installed in 1985 to trap the boulder dams of debris flows at an elevation of $1567 \mathrm{~m}$ ASL, just below the No. 6 dam. The flat rectangular board of the breaker, 10 $\mathrm{m}$ wide and $20 \mathrm{~m}$ long, was installed on a $4^{\circ}$ slope parallel to the original stream channel slope. The board consisted of 25 prismatic steel pipes, each 20 $\mathrm{m}$ long with rectangular cross-sections of $0.2 \times 0.2$ $\mathrm{m}$. The pipes were laid parallel to each other with 0.2-m spaces between them to drain off the watery slurry when subjected to debris flows (Kiyono et al., 1986; Imai et al., 1989; Nishimoto et al., 1994).

The July 21, 1985 debris flow of Fig. 8 arrived 

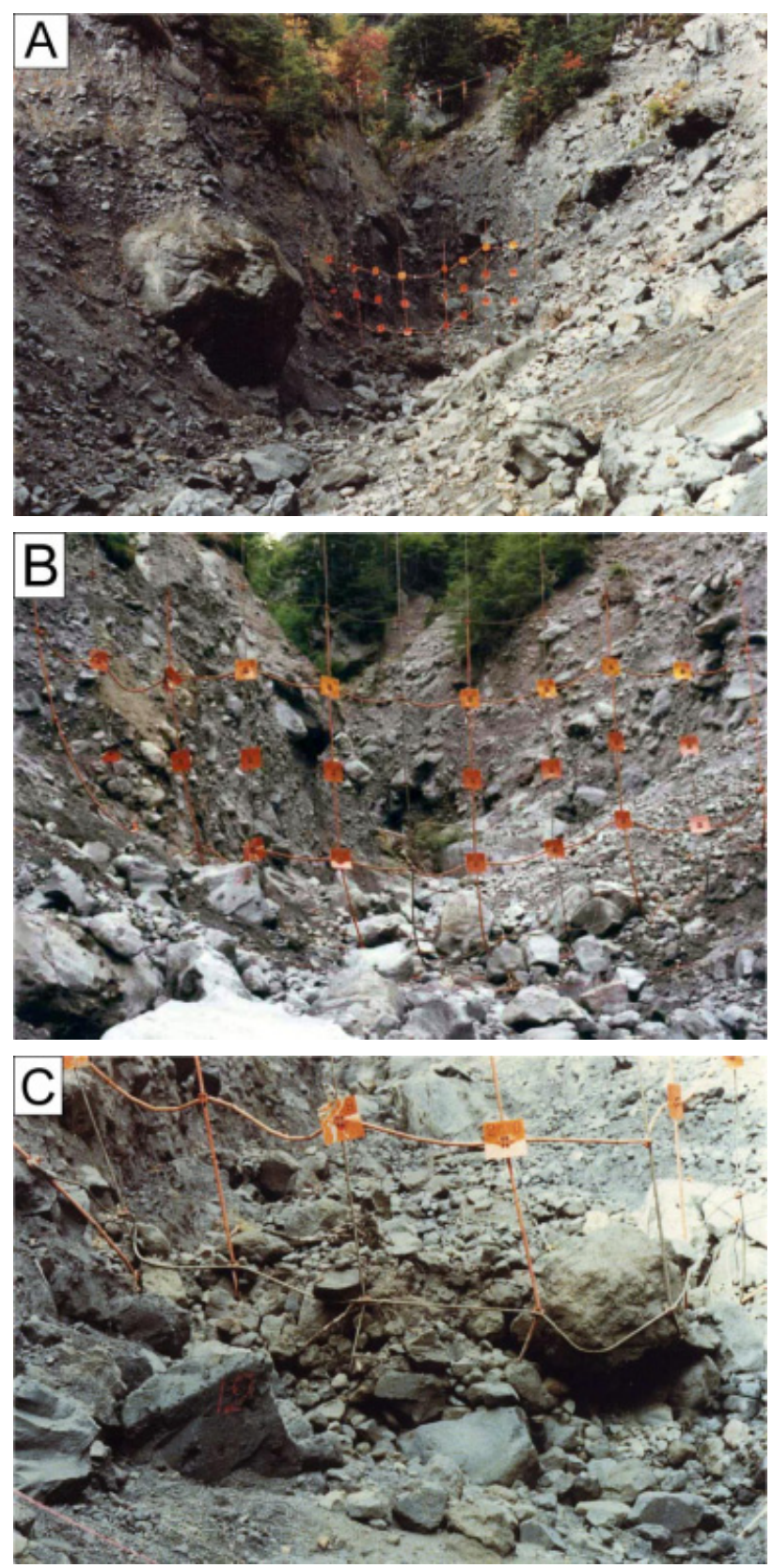

Fig. 12 Debris-flow breaker made of wire rope in a 2-m grid net. (A) Overall view of the net breaker on August 19, 1977. (B) The net on June 11, 1977 before the debris flow. (C) The net after the August 9, 1977 debris flow.

only six days after the completion of the breaker construction, and the frontal part of the debris flow was trapped as shown in Fig. 13. Although the 220 $\mathrm{m}^{3}$ of deposits trapped was only $5 \%$ of the total volume of $5500 \mathrm{~m}^{3}$ of this debris flow, the peak discharge of the flow must have been effectively reduced and the flow converted to a less-harmful level because of the reduced size of the boulder dam. In this event, the rear part of the first surge and the whole second surge passed through the breaker and were diverted to the lateral side routes. The sidewalls of the breaker were therefore subsequently reinforced. Specifically, the left side
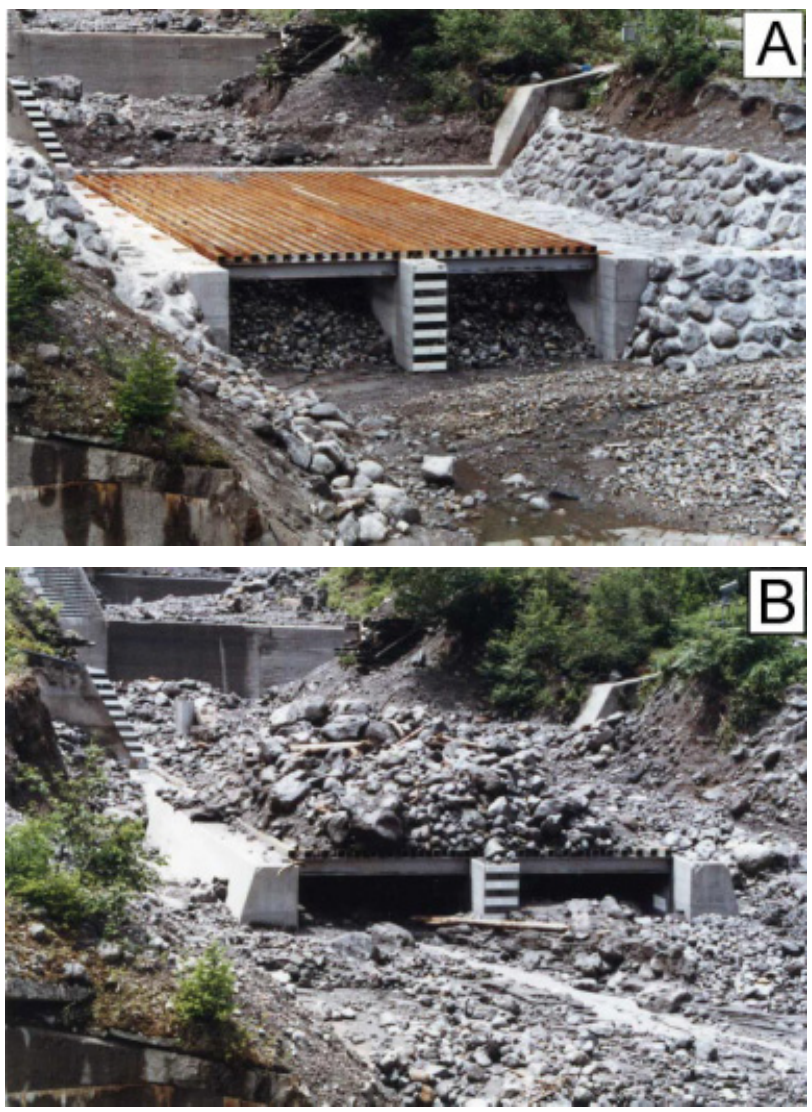

Fig. 13 Flat-board debris-flow breaker. (A) After removal of the July 21, 1985 debris-flow deposits and the construction of sidewall reinforcements. (B) Boulder deposits of the July 21,1985 debris flow trapped on the breaker (photo taken July 22, 1985).

was reinforced by a mortar lining and the right side was reinforced by a similar breaker board that was placed obliquely. After this modification, even if debris-flow boulder dams were trapped on the breaker, the rear part of succeeding flows would score the massive boulder deposits because the rear flows would not divert to the sides anymore because of the reinforcements. However, the peak discharge of debris flows were effectively reduced by the moderation processes, in which boulder dams were trapped abruptly and the deposits were gradually eroded to be incorporated into the flow at the recession limb.

This type of debris flow breaker was designed to separate coarse clastic debris from water with a fine debris matrix so that the water passes through the breaker board while the coarse debris is trapped (Izumi et al., 1982: Kurihara et al., 1987). However, the most effective mechanism in trapping boulder dams is as follows. Large boulders are transported in debris flows with less internal and boundary friction because they are effectively supported by large buoyancy due to the high density of the interstitial slurry. However, boulders completely 

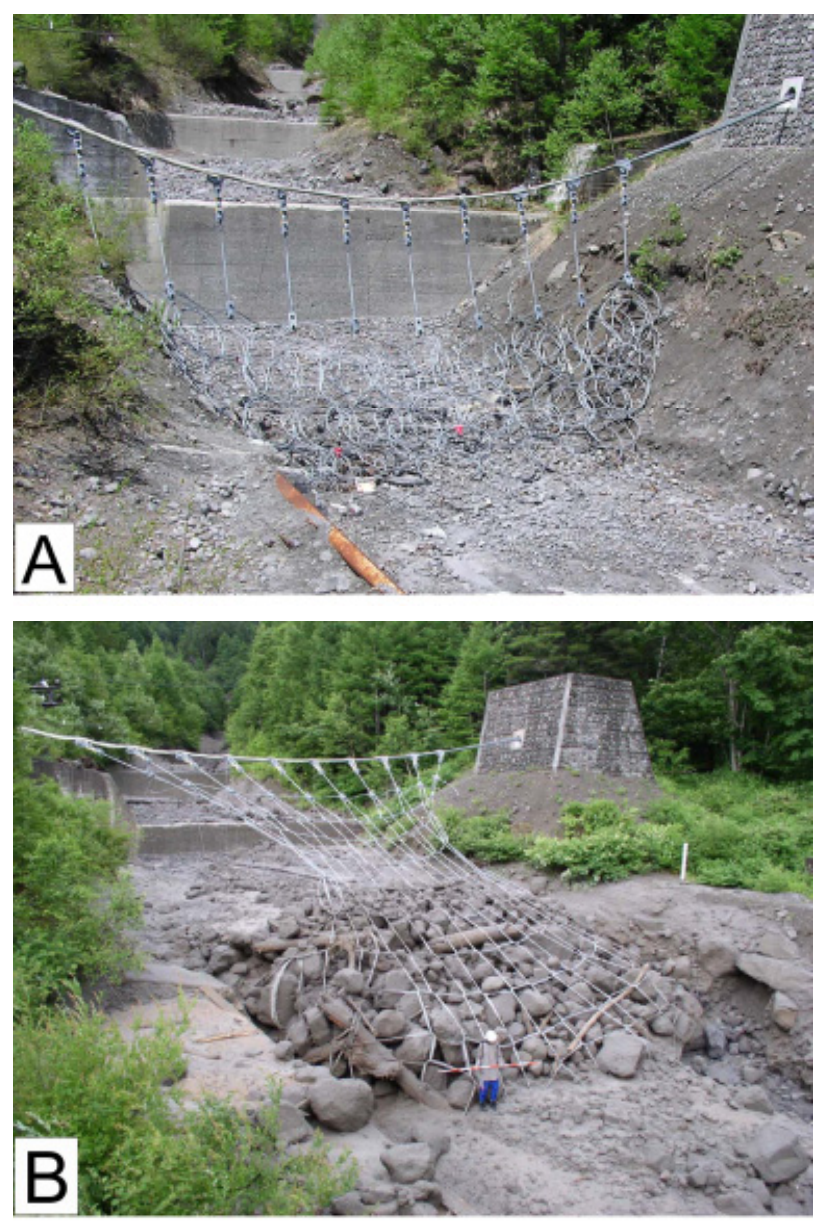

Fig. 14 Ring-net debris-flow breaker. (A) Photo on May 24, 2004, before the debris flows. (B) Boulder deposits of the July 18, 2004 debris flow trapped by the ring-net breaker (photo taken July 19, 2004)

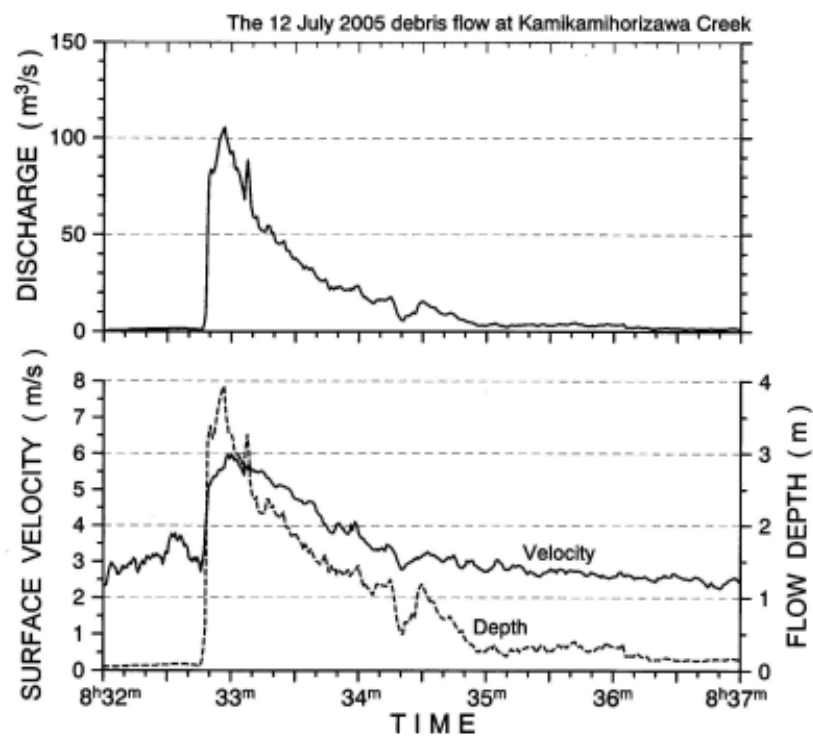

Fig. 15 Hydrograph of the July 12, 2005 debris-flow. After DPRI Kyoto Univ. (2006).

lose their buoyancy as soon as the flow arrives on the breaker due to the change in the fluid pressure distribution of the flow from a hydrostatic pressure regime into a quasi-atmospheric one. Therefore, the boulders suddenly sink and interlock each other under the large friction force, and cease to move.

\subsection{Ring net debris-flow breaker}

Another type of net dam was installed in 2002 at $1567 \mathrm{~m}$ ASL, just above the flat-board debris-flow breaker, to test the effectiveness of the breaker at trapping debris-flow boulder dams. Figure 14 shows the ring-net breaker that captured the boulder dam of the July 18, 2004 debris flow. The ring net consisted of many circular steel wire rings, $1.4 \mathrm{~m}$ in diameter; these rings were woven to form a skirt-shaped net $15 \mathrm{~m}$ wide and $5 \mathrm{~m}$ tall at the center (Imai et al., 2005; Momma et al., 2006). The net stretched as it absorbed collision forces when capturing debris flows. The ring net was able to withstand the impact of larger debris flows better than previous nets because of its shock-absorbing structure. This type of breaker could also be reused. Each ring became a rectangle when the net trapped debris flows, as shown in Fig. 14, and regained its round shape when the net was reset by the removal of the deposits.

In the case of the July 18, 2004 debris flow, the breaker captured $1800 \mathrm{~m}^{3}$ of deposits, which was $67 \%$ of the total $2700-\mathrm{m}^{3}$ volume of clastic debris that was discharged as a debris flow (DPRI Kyoto Univ., 2005). The July 12, 2005 debris flow was captured in a similar way by this breaker. The breaker captured $2090 \mathrm{~m}^{3}$ of deposits, which was $54 \%$ of the total $3880-\mathrm{m}^{3}$ volume discharged as a debris flow. However, analysis of video records showed that the sediments of the $2090-\mathrm{m}^{3}$ captured volume were the sum of the deposits brought about both by the debris-flow surge and by the successive hyper-concentrated stream flow. Figure 15 shows the hydrograph of this debris flow that descended as a single episode. The debris-flow surge and successive hyper-concentrated stream flow deposited sediments, as shown in Fig. 16, with a temporal change in volume stored in the channel spaces above the ring net breaker (DPRI Kyoto Univ., 2006). About $84 \%$ of the sediment was due to the debris-flow surge and $16 \%$ due to hyper-concentrated stream flows.

\section{CONCLUSION}

This paper has reviewed and described debris-flow behaviors at monitoring test sites in Kamikamihorizawa Creek, Mount Yakedake. The data recorded at this creek that relate to triggering rainfalls and runoffs, including debris-flow hydrographs, video sequences, termination 


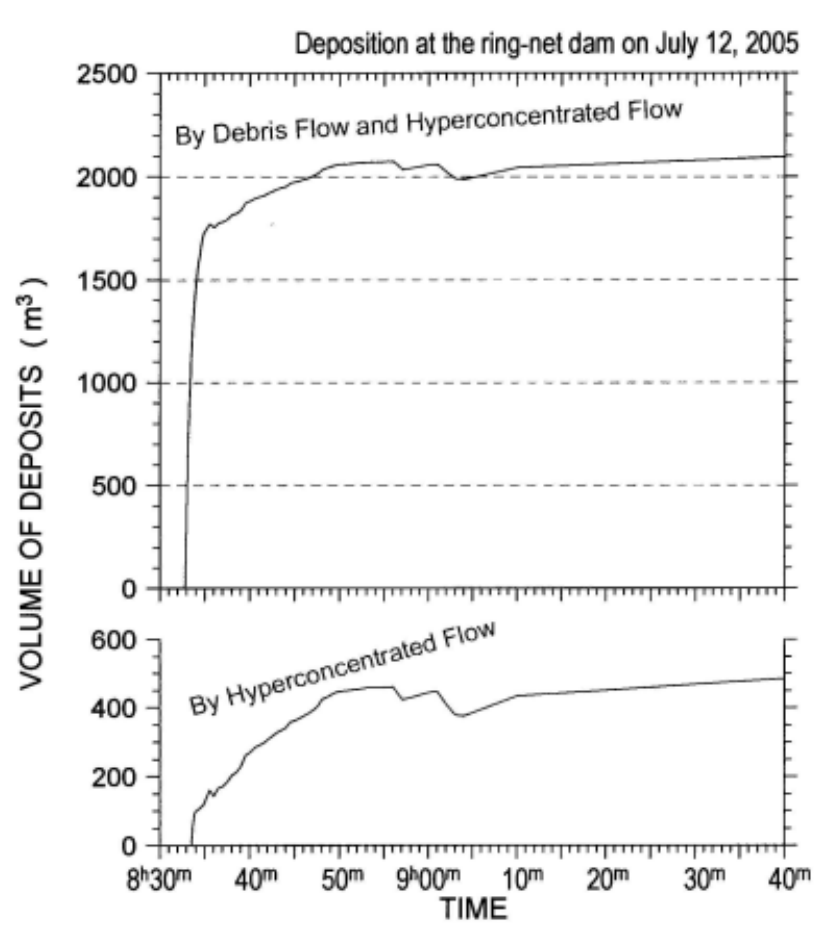

Fig. 16 Temporal change in the volume of the July 12, 2005 debris-flow deposits trapped by the ring-net debris-flow breaker. After DPRI Kyoto Univ. (2006).

processes, and changes in the topography of the gully and the fan, constitute one of the largest and longest-duration debris-flow monitoring projects in the world. The data gathered characterize the processes of debris flows as follows. 1) High-intensity rainstorms of durations as short as 10 min are more likely to trigger debris flows than a large amount of rainfall over a longer duration. This is relevant to the initiation process of erosion of gully-bottom deposits by storm runoff. 2) The lower threshold of rainfall intensities triggering debris flows has increased over the past 39 years due to the changes in hillslope hydrology, including the effects of post volcanic-eruption recovery in vegetation. 3) The hydrographs of debris-flow surges show mass and boulder focusing at the flow front that may be the result of several mechanical processes. 4) Pulsation and superelevation in debris flows are common to most cases, not only at Kamikamihorizawa Creek, but also elsewhere in the world, providing significant factors in hazard creation. 5) The monitoring of seismic signals of ground tremors radiated from debris flows is useful for hazard warning as well as for the estimation of debris-flow hydrographs. 6) Evaluation of downstream locations vulnerable to debris-flow hazards in alluvial fans is possible by considering the interactions of debris flows and fan-surface morphologies. 7) Moderation of debris-flow hydrographs is achievable using new types of debris-flow breakers at the downstream reaches near the gully exits.

Most of the processes described here are applicable not only for debris flows on volcanic slopes but also on other slopes where boulder-rich debris flows are likely. The methods of monitoring debris flows performed at Kamikamihorizawa Creek are highly recommended also in the future for solving problems against debris-flow hazards because some problems are difficult to ascertain by model experiments in flumes due to the differences in scales between the prototypes of actual phenomena and models.

ACKNOWLEDGMENTS: The authors thank the many students of Kyoto University and other universities who supported the debris-flow monitoring work in the field over the last 39 years. Two anonymous reviewers provided excellent suggestions for improvement to this manuscript. The debris-flow monitoring at Kamikamihorizawa Creek has been conducted as a joint study program between the Disaster Prevention Research Institute of Kyoto University and the Matsumoto Sabo Office of the Japanese Ministry of Land, Infrastructure, Transport, and Tourism. A portion of this study has been supported by many grants for scientific research from the Japanese Ministry of Education, Culture, Sports, Science, and Technology, including the recent grant-in-aid No. 19510188 .

\section{REFERENCES}

Arratano, M., Deganutti, A.M., and Marchi, L. (1997) Debris flow monitoring activities in an instrumented watershed on the Italian Alps, Proc. First Conf. on Debris-Flow Hazard Mitigation, ASCE, 506-515.

Davies, T. R., Phillips, C. J., Pearce, A. J., and Zhang, X. (1991) New aspects on debris flow behavior, Proc. Japan-U.S. Workshop on Snow Avalanche, Landslide, Debris Flow Prediction and Control, 443-451.

Disaster Prevention Research Institute of Kyoto University (1976) Study report of debris flow observation at Mount Yakedake in 1975, Technical report of Matsumoto Sabo Construction Office, Ministry of Construction, No. 5, 106, 1-48 (in Japanese).

Disaster Prevention Research Institute of Kyoto University (2005) Study report of debris flow observation at Mount Yakedake, Technical report of Matsumoto Sabo Office, Ministry of Land, Infrastructure, Transportation and Tourism, 86 pp. (in Japanese).

Disaster Prevention Research Institute of Kyoto University (2006) Study report of debris flow observation at Mount Yakedake, Technical report of Matsumoto Sabo Office, Ministry of Land, Infrastructure, Transportation and Tourism, 72 pp. (in Japanese).

Disaster Prevention Research Institute of Kyoto University (2008) Study report of debris flow observation at Mount Yakedake, Technical report of Matsumoto Sabo Office, Ministry of Land, Infrastructure, Transportation and 
Tourism, 78 pp. (in Japanese).

Genevois, R., Tecca, P.R., Berti, M., and Simoni, A. (2000) Debris-flows in the Dolomites: Experimental data from a monitoring system, Proc. 2nd Int. Conf. on Debris-Flow Hazards Mitigation, Wieczorek, G.F. and Naeser, N.D., eds., Balkema, ISBN 905809149 X, 283-291.

Haruyama, M., Jitousono, T., and Jomoto, K. (1984) Analyses of mud flows in Sakurajima Volcano, Journal of the Japan Society of Erosion Control Engineering, 37(2), 22-27 (in Japanese with English abstract).

Hooke, R. L. (1967) Processes on arid-region alluvial fans, Journal of Geology, 75, 438-460.

Ikeda, A., Monma, N., Horiuchi, S., and Yamada, T. (1998) Debris flows generated at Kitamata Valley of the Name River, Journal of the Japan Society of Erosion Control Engineering, 51(2), 31-38 (in Japanese with English abstract).

Ikeda, A. and Hara, Y. (2003) Flow properties of debris flows on the Kitamata Valley of the Name River, Japan, Proceedings of the 2nd International Conference on Debris-flow Hazards Mitigation, 851-862.

Imai, K., Miyamoto, N., and Mizuyama, T. (1989) Test of a debris-flow breaker at the Kamikamihori Valley, Mt. Yakedake (Part 2), Journal of the Japan Society of Erosion Control Engineering, 42(2), 16-20 (in Japanese).

Imai, K., Higuchi, J., Kasai, S., Momma, K., and Shimojo, K. (2005) Survey regarding the transformation and design of Kamikami-horizawa improved wire net dam, Journal of the Japan Society of Erosion Control Engineering, 58(4), 22-29 (in Japanese with English abstract).

Ishikawa, Y. (1985) Debris flows in the Name River, Journal of the Japan Society of Erosion Control Engineering, 37(5), 24-29 (in Japanese).

Itakura, Y. and Suwa, H. (1989) Measurement of surface velocity of debris flows by spatial filtering velocimetry, Proc. Japan-China Sym. on Landslides and Debris Flows, 199-203.

Iwasaki, T. (1968) Synthetic studies on the August 1967 Uetsu rainstorm disaster, Research Report of the Grant-in-Aid for Scientific Research of the Japanese Ministry of Education, 265 pp. (in Japanese).

Izumi, I., Watanabe, M., Takemura, T., and Mizuyama, T. (1982) Test of a bottom infiltration screen in Ohsawa Fan, Mt. Fuji, Journal of the Japan Society of Erosion Control Engineering, 34(3), 45-50 (in Japanese).

Johnson, A. M. (1970) Physical Processes in Geology, Freeman, Cooper \& Co., 445-459.

Kataoka, J., Takeda, Y., and Iida, O. (1984) An analysis of debris flow movement based on field observation, Journal of Japan Societey of Natural Disaster Science, 3(2), 41-50 (in Japanese with English abstract).

Kiyono, M., Miyakoshi, H., Uehara, S., and Mizuyama, T. (1986) Test of a debris flow breaker in the Kamikamihori Valley, Mt. Yakedake, Journal of the Japan Society of Erosion Control Engineering, 39(3), 15-19 (in Japanese).

Kobe Steel Ltd. (1975) Monitoring survey of sabo net dam, Technical report No. 5 of Matsumoto Sabo Office, Ministry of Construction, 91-105 (in Japanese).

Kobe Steel Ltd. (1978) Monitoring survey of sabo net dam, Technical report No. 9 of Matsumoto Sabo Office, Ministry of Construction, 131-152 (in Japanese).

Kurihara, J., Fukuzawa, M., and Iwata, Y. (1987) The report on mud flows that occurred at Osawa River, Mt. Fuji and function of the screen dam (prompt report), Journal of the Japan Society of Erosion Control Engineering, 40(3), 23-28 (in Japanese with English abstract).

Kurihara, J., Takezawa, N., Yamakoshi, T., and Yanagimachi,
T. (2007) Study on method of setting threshold of ground vibration sensor for detecting debris flow, Proc. 4th Int. Conf. on Debris-Flow Hazards Mitigation, Chen, C. and Major, J., eds., Millpress, 603-611.

Lavigne, F., Thouret, J., Voight, B., Suwa, H., and Sumaryono, A. (2000a) Lahars at Merapi volcano, Central Java: an overview, Journal of Volcanology and Geothermal Research, Vol. 100, 423-456.

Lavigne, F., Thouret, J., Voight, B., Young, K., LaHusen, R., Marso, J., Suwa, H., Sumaryono, A., Sayudi, D., and Dejean, M. (2000b) Instrumental lahar monitoring at Merapi Volcano, Central Java, Indonesia, Journal of Volcanology and Geothermal Research, Vol. 100, 457-478.

Lavigne, F. and Suwa, H. (2004) Contrasts between debris flows, hyperconcentrated flows and stream flows at a channel of Mount Semeru, East Java, Indonesia, Geomorphology, Vol. 61, 41-58.

Li, J., Yuan, J., Bi, C., and Luo, D. (1983) The main features of the mudflow in Jiang-Jia Ravine, Zeitschriftu fur Geomorphologie, 27(3), 325-341.

Ma, D. (1994) General study on the development and current situation of glacial debris flow in Guxiang gully, south-east of Tibet, China, in "Glacier Hazard System in Southeastern Tibet", Akamatsu, J. and Zhang, W., eds., Disaster Prevention Research Institute, Kyoto Univ., 65-73.

Marchi, M., Arratano, M., and Deganutti, A.M. (2002) Ten years of debris-flow monitoring in the Moscardo Torrent (Italian Alps), Geomorphology, 46, 1-17.

Marcial, S., Melosntos, A.A., Hadley, K.C., LaHusen, R.G., and Marso, N. (1996) Instrumental lahar monitoring at Mount Pinatubo, in "Fire and Mud: Eruption and Lahars of Mount Pinatubo, Philippines", Newhall, C.G. and Punongbayan, R.S., eds., , U. Washington Press, Seattle, 1015-1022.

Matsumoto Sabo Office (1979) Eruption records of Mount Yakedake, Technical report No.12 of Matsumoto Sabo Office of Ministry of Construction, 27pp. (in Japanese).

Momma, K., Watari, M., and Imai, K. (2006) Study on mechanism of capturing debris flow into wire networks, Journal of the Japan Society of Erosion Control Engineering, 58(5), 3-12 (in Japanese with English abstract).

Nanzaka, J. and Iwata, Y. (1989) Debris flows and frozen soil layer at the Osawa Collapse in Mt. Fuji, Journal of the Japan Society of Erosion Control Engineering, 42(4), 23-27 (in Japanese).

Nishimoto, H., Ishikura, K., Mizuyama, T., and Santosa, U.B. (1994) Behavior of a debris flow on the debris-flow breaker at Mount Yakedake, Journal of the Japan Society of Erosion Control Engineering, 46(6), 21-24 (in Japanese).

Okano, K., Suwa, H., and T. Kannno (2009) Rainstorm control of scale and type of debris flows at Kamikamihorizawa Creek of Mount Yakedake, Japan, Journal Japan Society of Erosion Control Engineering, 62(4), 3-10 (in Japanese with English abstract).

Okuda, S., Suwa, H., Okunishi, K., Yokoyama, K., and Nakano, M. (1980a) Observation of the motion of debris flow and its geomorphological effects, Zeitschrift fur Geomorphology, Suppl.-Bd.35, 142-163.

Okuda, S., Okunishi, K., and Suwa, G. (1980b) Obervation of debris flow at Kamikamihori Valley of Mt. Yakedake, Excursion Guide-Book for Sym. IGU Commission on Field Experiments in Geomorphology, 116-139.

Okuda, S., Suwa, S., Okunishi, K. and Yokoyama, K. (1981) Depositional processes of debris flow at Kamikamihori fan, Northern Japan Alps, Trans. Japan. Geomorph. Union, 2(2), $353-361$ 
Okuda, S. and Suwa, H. (1984) Some relationships between debris flow motion and microtopography for the Kamikamihori Fan, North Japan Alps, in "Catchment Experiments in Fluvial Geomorphology", Burt, T.P. and Walling, D.E., eds., Geo Books Norwich, 447-464.

Okunishi, K. and Suwa, H. (1985) Hydrological approach to debris flow, Proc. Int. Sym. on Erosion, Debris Flow and Disaster Prevention, Tsukuba (JSECE Publ.), 243-247.

Pierson, T.C. (1980) Erosion and deposition by debris flows at Mt. Thomas, North Canterbury, New Zealand, Earth Surface Processes, 5(3), 227-247.

Pierson, T.C. (1986) Flow behavior of channelized debris flows, Mount St. Helens, Washington, in "Hillslope Processes", Abraham, A.D., ed., Boston, Allen \& Unwin, 269-296.

Plafker, G. and Ericksen, G.E. (1978) Nevados Huascaran avalanche, Peru, in "Rockslides and Avalanches 1", Voight, B., ed., Elsevier Scientific Publishing Co., 277-314.

Saita, M., Yamauchi, O., Totsugi, S., and Koga, S. (1980) A report on debris-flow observation at Mount Sakurajima, Journal of the Japan Society of Erosion Control Engineering, 33(2), 26-29 (in Japanese).

Saito, R. (1973) Records of rainstorm, in "Rainstorms: New Hazards and Mitigation", Saito, R., Okuda, S., and Saito R., Japan Broadcast Publishing Co. Ltd., 16-71 (in Japanese).

Suwa, H., Okuda, s., and Yokoyama, K. (1973) Observation system on rocky mudflow, Bull. Disas. Prev. Res. Inst., Kyoto Univ., No. 23, 59-73.

Suwa, H. and Okuda, S. (1980) Dissection of valleys by debris flows, Zeitschrift fur Geomorphology, Suppl.-Bd.35, 164-182.

Suwa, H. and Okuda, S. (1983) Deposition of debris flows on a fan surface, Mt. Yakedake, Japan, Zeitschrift fur Geomorphology, Suppl.-Bd.46, 79-101.

Suwa, H., Shikata, T., and Okuda, S. (1983) Topographical change on the sidewall and in the valley bottom of the Kamikamihori Valley of Mt. Yakedake, Ann. Disaster Prevention Research Institute, Kyoto Univ., 26(B1), 413-433 (in Japanese with English abstract).

Suwa, H. and S. Okuda (1985) Measurement of debris flows in Japan, Proc. 4th Int. Conf. and Field Workshop on Landslides, Tokyo, 391-400.

Suwa, H. (1988) Focusing mechanism of large boulders to a debris-flow front, Trans. Japanese Geomorphological Union, 9(3), 151-178.

Suwa, H. and Okuda, S. (1988) Seasonal variation of erosional processes in the Kamikamihori Valley of Mt. Yakedake, Northern Japan Alps, CATENA, Suppl.-Bd. 13, 61-77.

Suwa, H. (1989) Field observation of debris flow, Proc. Japan-China (Taipei) Joint Seminar on Natural Hazard Mitigation, Kyoto, 343-352.

Suwa, H., Okunishi, K., and Sakai, M. (1993) Motion, debris size and scale of debris flows in a valley on Mount Yakedake, Japan, IAHS Publ. No. 217, 239-248.

Suwa, H., Ma, D., and Zhao, S. (1994) Observation of glacial debris flow at Guxiang gully in 1992, in "Glacier Hazard System in Southeastern Tibet", Akamatsu, J. and Zhang, W., eds., Disas. Prev. Res. Inst. Kyoto Univ., 75-85.

Suwa, H. and Sumaryono, A. (1996) Sediment discharge by storm runoff from a creek on Merapi Volcano, Jour. Japan. Soc. Erosion Control Engineering, Vol. 48, Special issue, 117-128.

Suwa, H. and Yamakoshi, T. (1997) Eruption, debris flow and hydrogeomorphic condition at Mount Unzen, Proc. First Conf. on Debris-Flow Hazard Mitigation, ASCE, 289-298.

Suwa, H., Sawada, T., Mizuyama, T., Arai, M., and Takahashi, T. (1997) Observational study on viscous debris flows and countermeasures against them, Proc. Int. Sym. on Natural
Disaster Prediction and Mitigation, organized by DPRI, Kyoto Univ., 225-230.

Suwa, H. and Yamakoshi, T. (1999) Sediment discharge by storm runoff at volcanic torrents affected by eruption, Zeitschrift fur Geomorph. N. F., Suppl.-Bd. 114, 68-88.

Suwa H. and Yamakoshi, T. (2000) Estimation of debris-flow motion by field survey, in Proc. 2nd Int. Conf. on Debris-Flow Hazards Mitigation: Mechanics, Prediction, and Assessment, Wieczorek, G.F. and Naeser, N.D., eds., Balkema, 293-299.

Suwa, H., Yamakoshi, T., and Sato, K. (2000) Relationship between debris-flow discharge and ground vibration, in Proc. 2nd Int. Conf. on Debris-Flow Hazards Mitigation: Mechanics, Prediction, and Assessment, Wieczorek, G.F. and Naeser, N.D., eds., Balkema, 311-318.

Suwa, H., Akamatsu, J., and Nagai, Y. (2003) Energy radiation by elastic waves from debris flows, in Proc. 3rd Int. Conf. on Debris-Flow Hazards Mitigation: Mechanics, Prediction, and Assessment, Rikkenmann, D. and Wieczorek, G.F., eds., Balkema, 895-904.

Suwa, H. and Nakaya, S. (2007) Two catastrophic debris avalanches triggered by rainstorms in Japan and Philippines, in Proc. 4th Int. Conf. on Debris-Flow Hazards Mitigation: Mechanics, Prediction, and Assessment, Chen, C., and Major, J., eds., 341-351.

Takahashi, T. (1980) Debris flow on prismatic open channel, J. Hydraulics Div., ASCE, 106(HY3), 381-396.

Thouret, J.-C., Lavigne, F., Suwa, H., Sukatja, B., and Surono, (2007) Volcanic hazards at Mount Semeru, East Java (Indonesia), with emphasis on lahars, Bulletin of Volcanology, 70(2), 221-244.

Yamakoshi, T. and Suwa, H. (2000) Post-eruption characteristics of surface runoff and sediment discharge on the slopes of pyroclastic-flow deposits, Mount Unzen, Japan, Trans. Japan. Geomorph. Union, 21(4), 469-497.

Yamakoshi, T, Mizuyama, T., Suwa, H., Okunishi, K., and Nakano, M. (2001) A two-decade hydrologic change at the source area of Kamikamihori Gully, Mount Yakedake, J. Japan Soc. Erosion Control Eng., 54(4), 22-32 (in Japanese with English abstract). 